\title{
11. Population Analysis of the DNA Content in Adenocarcinoma Cells by Means of Flow Micro.Fluorometry
}

\author{
By Iwao NishiYa and Yoshiaki IsHIZAKI \\ Department of Obstetrics and Gynecology, School of Medicine, \\ Hokkaido University, Sapporo \\ (Communicated by Sajiro Makino, M. J. A., Feb. 13, 1978)
}

When the nuclear DNA content of the cell is considered with regard to the cell cycle, it is diploid (2c) in the $\mathrm{G}_{1}$-phase. When it enters the S-phase, it is duplicated in DNA synthesis, while in the $\mathrm{G}_{2}$-phase where it becomes a tetraploid (4c) it is divided into two diploid cells (Kramer et al. 1973). However, in cells undergoing a remarkable proliferation it has been noted that the cell population not only increases in size in the S-phase and $\mathrm{G}_{2}$-phase, but also proceeds to a hypertetraploid range becoming octoploid (8c). In addition, as malignancy tends to increase under this condition, there appear aneuploid cells in the cell population. In order to analyse such an abnormal behavior in cell kinetics, our experiments have generally been performed by means of microspectrophotometry (MSP) by which the nuclear DNA content of cells was measured by subjecting them to Feulgen reaction (Nishiya et al. 1977), or by the autoradiographic technique involving the uptake of ${ }^{3} \mathrm{H}$-thymidine in cells (Shimotomai et al. 1975). However, both methods involve a complicated procedure which requires considerable time, and only a limit of cells could be investigated in those experiments.

In the United States where Coulter counter research became possible to obtain the number and size of cells based on the theory of light scattering using cell effusion, the adoption of exitation of the Laser beam together with Laminar flow was introduced in the experiment, and as a result rapid flow microfluorometry (FMF) was developed which has made possible through the selection of fluorescent dye a simultaneous measurement of the nuclear DNA content and the histone volume.

In the present paper, we wish to describe some results of FMF measurement of adenocarcinoma cells derived from human genital tracts. Previously, there was a considerable difficulty in obtaining objective criteria in such materials by histological and cytological examinations.

Materials and method. The glandular epithelial cells of the 
cervix were scraped by wooden spatula, and the endometrial cells were suctioned by a cannula. In addition, the fluid of the ovarian cysts was aspirated. Cell effusions of a similar origin from normal women were used as control. The cells for experiments were fixed in the form of a cell suspension in $50 \%$ ethanol $10 \mathrm{ml}$ and stored at $4^{\circ} \mathrm{C}$. The cell samples thus prepared were spread by autosmearing homogeneously and dispersely, and subjected to Feulgen staining. Use being made of a micro-spectrophotometer (MSP-Olympus Co., Ltd.), the nuclear DNA content was measured in 100 cells and a histogram was obtained. Further, $5 \mathrm{ml}$ of the cell suspension was subjected to syringing to lower the cell aggregation, and after passing through a mesh filter of 100 micron in diameter, $0.1 \%$ acridine-orange $0.05 \mathrm{ml}$ in volume was added for fluorescent staining. Ten minutes thereafter, the measurement of the DNA content was done by a flow microfluorometer (Biophysics Type-E, USA). Laser exitation was made by a maximum wavelength of $488 \mathrm{~nm}$ with $10 \mathrm{~mW}$ output laser source, and the pulse signal was displayed on 1024 channel using two photomultipliers. At the time when the channel peak was measured at the level of 500 cells, the distribution curve was investigated.

Three cases of undifferentiated adenocarcinoma of the cervix, 6 cases of moderate differentiated adenocarcinoma of the endometrium and 3 cases of serous cystadenocarcinoma of the ovary came under measurement in the present study (for detail see Table I). The

Table I. DNA distribution patterns of adenocarcinoma in genital tract by flow-microfluorometry

\begin{tabular}{|c|c|c|c|c|c|c|}
\hline & Cases & Age & Histology & $\begin{array}{l}\text { obtained } \\
\text { by }\end{array}$ & $\begin{array}{l}\text { Number of } \\
\text { Cells measured }\end{array}$ & $\begin{array}{l}\text { Nuclear DNA }(2 c=\text { diploid }) \\
\text { Mode and Range }\end{array}$ \\
\hline $\begin{array}{l}\frac{x}{2} \\
\text { J }\end{array}$ & $\begin{array}{l}\text { R. O. } \\
\text { S. A. } \\
\text { M. M. } \\
\text { M. T. }\end{array}$ & $\begin{array}{l}52 \\
44 \\
53 \\
47\end{array}$ & $\begin{array}{l}\text { Reserve cell hyperplasia } \\
\text { Adenoca. undifferentiate } \\
\text { Adenoca. undifferentiate } \\
\text { Adenoca. undifferentiate }\end{array}$ & $\begin{array}{l}\text { Scraping } \\
\text { Scraping } \\
\text { Scraping } \\
\text { Scraping }\end{array}$ & $\begin{array}{r}70615 \\
128810 \\
52710 \\
102220\end{array}$ & 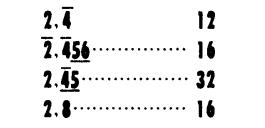 \\
\hline 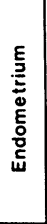 & $\begin{array}{l}\text { S. S. } \\
\text { Y.K. } \\
\text { T. I. } \\
\text { T. K. } \\
\text { M. Y. } \\
\text { H. U. } \\
\text { H. O. }\end{array}$ & $\begin{array}{l}59 \\
17 \\
50 \\
50 \\
19 \\
65 \\
54\end{array}$ & $\begin{array}{l}\text { Normal endometrium (atrophy) } \\
\text { Adenoca. moderate diff. } \\
\text { Adenoca. moderate diff. } \\
\text { Adenoca. well diff. } \\
\text { Adenoca. well diff. } \\
\text { Adenoca. well diff. } \\
\text { Adenoca. well diff. }\end{array}$ & $\begin{array}{l}\text { Aspiration } \\
\text { Aspiration } \\
\text { Aspiration } \\
\text { Operation } \\
\text { Aspiration } \\
\text { Aspiration } \\
\text { A \& C } \\
\text { Aspiration } \\
\text { \& C C }\end{array}$ & $\begin{array}{r}31793 \\
114048 \\
151895 \\
112273 \\
90126 \\
61345 \\
132140\end{array}$ & 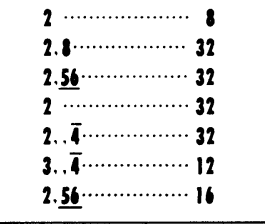 \\
\hline ô & $\begin{array}{l}\text { T. H. } \\
\text { H. Y. } \\
\text { R. O. } \\
\text { M. T. }\end{array}$ & $\begin{array}{l}54 \\
48 \\
50 \\
58\end{array}$ & $\begin{array}{l}\text { Serous cysto adenoma } \\
\text { Papillary serous cystoddenoca. } \\
\text { Papillary serous cystoadenoca. } \\
\text { Papillary serous cystoadenoca. }\end{array}$ & $\begin{array}{l}\text { Aspiration } \\
\text { Ascites } \\
\text { Ascites } \\
\text { Ascites }\end{array}$ & $\begin{array}{r}25614 \\
169811 \\
94553 \\
90867\end{array}$ & 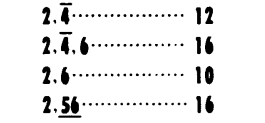 \\
\hline
\end{tabular}

Population analysis of nuclear DNA content of adenocarcinoma cells originating in the cervix, endometrium and ovary by FMF method. The line with figures of mode indicates the site where a modal peak is formed. 
results obtained in the experiments are presented in the following.

Results and discussion. In order to obtain the diploid peak, the measurement was firstly made in peripheral normal lymphocytes. In a total of 41898 cells measured, the distribution curve was shown as a narrow ranged single peak (Fig. 1). The measurement of MSP showed that $68 \%$ of the cells formed a diploid peak, while $10 \%$ of the total lymphocytes showed a tetraploid peak.

The measurement of three cases of undifferentiated adenocarcinoma of the cervix resulted in the formation of the second peak in the diploid area (Fig. 3a), with the first mode lying in the tetraploid to hexaploid ranges. As seen in Fig. 3b, endometrial adenocarcinoma likewise showed the formation of two modes, with the exception of one case in which these modes were recognized between diploidy and hypertetraploidy and the range extended up to the octoploid area. While a few numbers of cells with a high DNA content such as $32 \mathrm{c}$ was recognized in a total of 61000-135000 cells, it may be surmised that such cells with a high DNA content were extremely limited in number.

When the cell effusion derived from three cases of serous cystadenocarcinoma of the ovary was applied for measurement, a narrow, sharply pointed peak was obtained in a diploid range (Fig. 3c). At the same time, there was a wide distribution in the sample ranging from tetraploid to hexaploid areas. The fact that numerous prolifer-

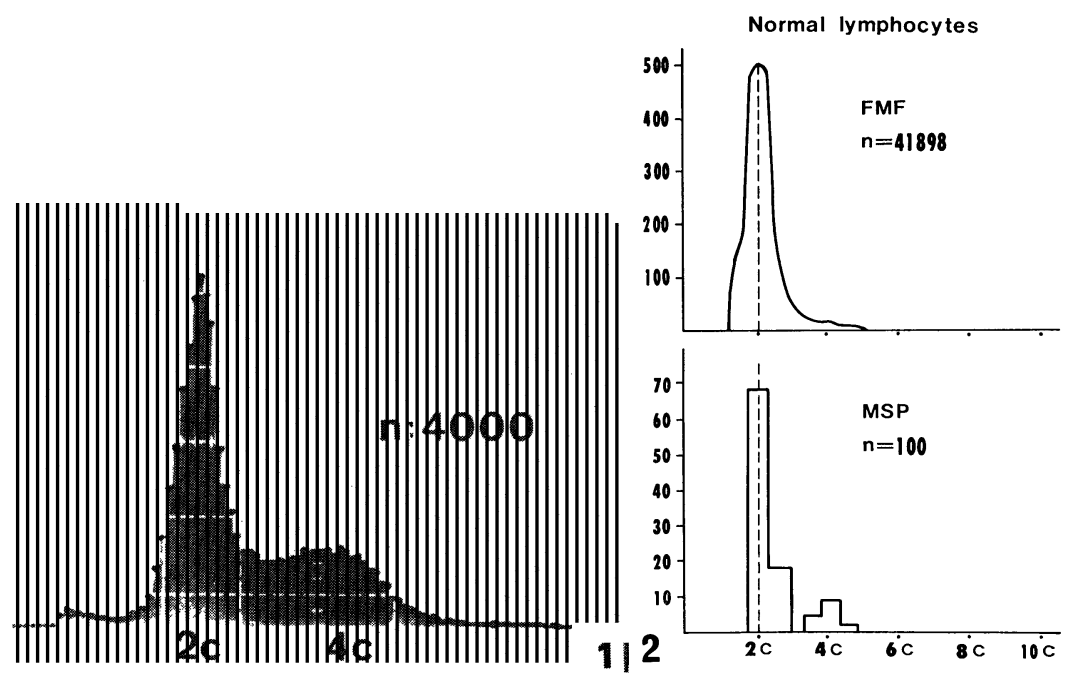

Fig. 1. Nuclear DNA histogram by FMF. Distribution curve derived from measurement of $4000 \mathrm{HeLa}$ cells.

Fig. 2. The relationship between FMF and MSP in nuclear DNA distribution of normal lymphocytes. 
[Vol. $55(\mathrm{~B})$,

ating cells at a tetraploid range were present in the sample is of considerable clinical interest referring to the evidence that approximately $70 \%$ of the ovarian adenocarcinoma arises from the benign cystoma secondarily.
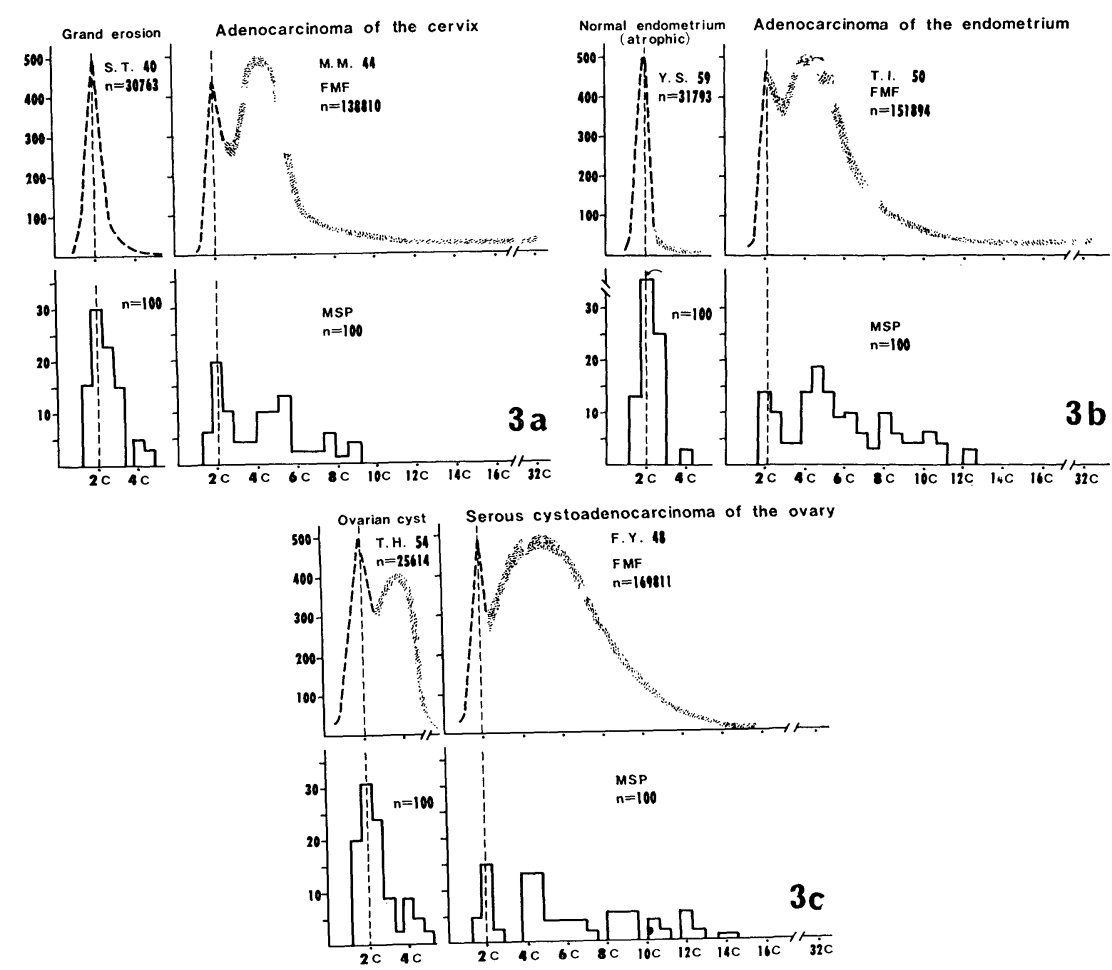

Fig. 3. FMF mode and range of nuclear DNA distribution curve of adenocarcinoma cells in contrast to those histogram of normal and benign lesions in the cervix (a) endometrium (b) and ovary (c) by MSP.

By applying scattering sensors according to the FMF techniques to the sample, the distribution of the number and size of cells can be measured (Mullaney et al. 1970). When the intensity of green fluorescence in acridine-orange staining is measured by $510-540 \mathrm{~nm}$ emission in maximum wavelength, the nuclear DNA content can be observed, and at the same time it becomes possible to measure histone and protein by means of the red fluorescence on $630 \mathrm{~nm}$ emission. Since the FMF method makes it possible to measure the fluorescent excitation in considerable rapidity (Crissman et al. 1974), the previous disadvantage of fading which has been the bane of the fluorescent measurement has been completely abolished so far (Nishiya et al. 1976). Moreover, since an extremely fine laminar flow can be obtained by improvement of the sheath through system, it becomes pos- 
sible to analyse the cell population amounting $10^{4}-10^{6}$.

Following the FMF method we have been studying the cells of adenocarcinoma developed on the uterus and the ovary in an aim to investigate the change of the nuclear DNA content which may be considered as the biological behavior of malignant cells. Recently Crissman et al. (1976) and Fowlkes et al. (1976) developed the dual parameter system by which, in addition to the nuclear DNA content, histone and protein volumes can be measured simultaneously. Mention should be made that cell biologic research with the FMF method is very useful in studying what correlations are present in relation to the proliferation and differentiation of adenocarcinoma cells.

Substances such as those which may affect the binding of fluorescent dye to the nuclear DNA and histone could be expected to change fluorescent intensity independent of true change in the DNA content. Studies of DNA fluorescence by the use of other DNA fluorochromes such as ethidium bromide have currently been in progress.

We are grateful to Emeritus Professor Dr. S. Makino, M. J. A., for his revision of the manuscript. The study was supported by grants from the Ministry of Education(No. 257403) and the Ministry of Health and Welfare of Japan.

\section{References}

Kramer, P. M., Deaven, L. L., Crissman, H. A., Steinkamp, J. A., and Petersen, D. F. (1973) : Cold Spring Harbor Symp. Quant. Biol., 38, 133-144.

Nishiya, I., Kikuchi, T., Moriya, S., and Sawamura, I. (1977) : Acta Cytol., 21, 271-275.

Shimotomai, K. (1975) : Acta Obstet. Gynec., 22, 59-66.

Mullaney, P. F., and Dean, P. N. (1970): Biophys. J., 10, 764.

Crissman, H. A., and Tobey, R. A. (1974) : Science, 184, 1297-1298.

Nishiya, I., Takeyama, S., Moriya, S., and Kikuchi, T. (1976) : Obstet. Gynec. Therapy, 32, 98-107.

Crissman, H. A., Oka, M. S., and Steinkamp, J. A. (1976) : J. Histochem. Cytochem., 241, 641.

Fowlkes, B. J., Herman, C. J., and Cassidy, M. (1976) : J. Histochem. Cytochem., 24, 332 . 